\title{
RADIATION EFFECT OF WIRELESS FIDELITY (Wi-Fi) ON OOCYTE NUMBER OF OOCYTE STIMULATION IN MICE (Mus Musculus)
}

\author{
Anita Nurbayatin ${ }^{1}$, Widjiati ${ }^{2}$, Relly Yanuari Primariawan ${ }^{3}$, Bambang Poernomo $^{2}$, Sulistiawati ${ }^{4}$, Rina Yudiwati ${ }^{5}$ \\ ${ }^{1}$ Reproductive Health Master Program, Faculty of Medicine, ${ }^{2}$ Department of Embriology, Faculty of Veterinary \\ Medicine, ${ }^{3}$ Department of Obstretics and Gynecology, Faculty of Medicine, ${ }^{4}$ Department of Public Health and \\ Preventive Medicine, Faculty of Medicine, ${ }^{5}$ Department of Medical Biomedic, Faculty of Medicine, Universitas \\ Airlangga, Surabaya, Indonesia
}

\begin{abstract}
ABSTRAK
Infertilitas merupakan masalah yang dialami oleh sebagian wanita dan pria di seluruh dunia. Sebagian besar masalah ketidaksuburan pada wanita disebabkan oleh gangguan organ reproduksi atau gangguan ovulasi. Salah satu faktor yang menyebabkan gangguan pematangan oosit adalah radiasi wireless fidelity (Wi-Fi) yang mempunyai bidang frekuensi radio sebesar 2,45 GHz. Radiasi tersebut dapat meningkatkan aktivitas sel radikal bebas melalui jalur reaksi fenton yang menyebabkan infertilitas karena mengganggu perkembangan oosit. Penelitian ini bertujuan untuk mengetahui pengaruh radiasi Wi-Fi terhadap jumlah oosit. Penelitian ini merupakan penelitian eksperimental menggunakan rancangan kelompok kontrol. Subjek penelitian adalah 32 mencit betina yang telah dipilih melalui complete random sampling dan dibagi menjadi dua kelompok: kontrol (R0) dan paparan (R1). Setiap kelompok terdiri dari 16 ekor mencit. Frekuensi radio Wi-Fi yang digunakan adalah 2,5 GHz. Tikus (R1) didekatkan pada sumber Wi-Fi $( \pm 15 \mathrm{~cm})$, dan terdapat dua jenis laptop PC dan handphone $3 G$ yang terhubung dengan koneksi internet yang diletakkan di samping tempat tikus selama 15 jam/28 hari. Tikus-tikus tersebut menjalani siklus simultan dengan injeksi intraperitoneal PMSG dan HCG. Selanjutnya, mencit-mencit tersebut dikawinkan dengan pejantan tervasektomi untuk menginduksi ovulasi. Kantung fertilisasi pada kedua saluran telur diamati untuk pengumpulan oosit. Jumlah oosit dihitung menggunakan mikroskop terbalik. Terdapat perbedaan jumlah oosit antara kelompok kontrol dan kelompok paparan. Uji statistik dianalisis menggunakan Mann Whitney $U$ dan menghasilkan nilai signifikan ( $p$ value=0,00). Tidak ada oosit yang masuk ke dalam kelompok paparan. Dengan kata lain, kelompok tersebut mendapatkan anovulasi. Sebagai kesimpulan, radiasi Wi-Fi berpengaruh terhadap jumlah stimulasi oosit pada tikus. Oleh karena itu, sangat penting untuk meminimalkan faktor risiko yang memicu radiasi elektromagnetik pada kesehatan reproduksi. (FMI 2017;53:169-172)
\end{abstract}

Kata kunci: radiasi Wi-Fi; ovulasi; jumlah oosit

\begin{abstract}
Infertility is a problem experienced by some women and men around the world. Most infertility problems in women is caused by impaired reproductive organs or disrupted ovulation.. One factor that causes impaired oocyte maturation is wireless fidelity (Wi-Fi) radiation which has a radio frequency field of $2.45 \mathrm{GHz}$. The radiation may increase the activity of free radical cells through the fenton reaction pathways that cause infertility because of the disrupted oocyte development. This study aimed to determine the effect of Wi-Fi radiation on the number of oocytes. This was an experimental study using control group design. The subjects were 32 female mice selected through complete random sampling and divided into two groups: control (RO) and exposure (R1). Each group consisted of 16 mice. The Wi-Fi radio frequency used was $2.5 \mathrm{GHz}$. Mice (R1) were placed closer to Wi-Fi source ( $\pm 15 \mathrm{~cm})$, and there were two types of laptop PCs and $3 G$ mobile phones connected to internet placed next to mice for 15 hours $/ 28$ days. The mice underwent a simultaneous cycle with intraperitoneal injection of PMSG and HCG. Furthermore, the mice were mated with vasectomized male monomatingly to induce ovulation. The fertilization pouch in both oviducts were observed for oocyte collection. The number of oocytes was calculated using an inverted microscope. There was a difference in the number of oocytes between control and exposure group. Statistical tests were analyzed using Mann Whitney $U$ and resulted in significant values $(p$ value $=$ 0.00). No oocytes count in exposure group. In other words, the group underwent anovulation. In conclusion, Wi-Fi radiation affected the number of oocyte stimulation in mice. Therefore, it was important to minimize the risk factors that trigger electromagnetic radiation on reproductive health. (FMI 2017;53:169-172)
\end{abstract}

Keywords: Wi-Fi radiation; ovulation; oocyte number

Correspondence: Anita Nurbayatin, Jalan Raya Menganti Hulaan, Gresik 6074, Indonesia. Email: anitanurbayatin@yahoo.co.id 


\section{INTRODUCTION}

Wireless technology has developed very rapidly throughout the year, as with public demand for information technology that is easy to access. Wireless fidelity (WiFi) allows to simplify the use of technology tools that can connect a person with internet easily, so that the internet becomes a necessity for all people. Because of the increasingly widespread phenomenon of internet access provider facilities in Indonesia at this time, internet access is not only found in internet cafes, but also in all public areas that have installed Wi-Fi hotspot. It can be said that people currently cannot to be far from the internet.

Radiation is often considered as something harmful and detrimental to health. Radiation is basically the process of heat transfer through the electromagnetic waves, energy (photons) that could propagate through very long distances without requiring interaction with the medium. Radio waves (Radio Frequency-Electromagnetic Field) are placed in frequencies between $3 \mathrm{KHz}-300$ $\mathrm{GHz}$. One example of the use of radio waves is Wireless Fidelity (Wi-Fi) which has the frequency of $2.4 \mathrm{GHz}$. The wavelength of Wi-Fi is $12.5 \mathrm{~cm}$, which means that this frequency has wavelength of $12.5 \mathrm{~cm}$.

The exposure to the radiation of $2.45 \mathrm{GHz}$ may possibly produce oxidative stress in dorsal root ganglion (nodule on a dorsal root of the spine that contains cell bodies of nerve cells that carry signals from sensory organs toward the appropriate integration center), and melatonin (hormone regulating reproductive cycle) may avert this kind of reaction. The International Agency for Research on Cancer (IARC 2011) also confirmed that exposure to Wi-Fi radiation is a potential carcinogen. Electromagnetic fields may have impact on cells and DNA. The attributes of DNA promote greater reactivity to electromagnetic fields than other tissues, generating the long term implication (Karki 2013). Reproduction organs function as main functional organism. If there are impaired reproductive organs, subfertility and abnormal embryo development may occur. Radiation exposure due to radio electromagnetic of the $\mathrm{Wi}-\mathrm{Fi}$ as a risk factor causes infertility problems (Poulettier de Gannes et al 2013).

Infertility is a problem experienced by some women and men all over the world. Most of the infertility problems according to World Health Organization (WHO) in 2014 were: impaired tube $(30 \%)$, disrupted ovulation $(33 \%)$, endometriosis $(30 \%)$, and unknown $(26 \%)$, It means that most of infertility problems in women are caused by impaired reproductive organs or disrupted ovulation. One factor that induces impaired folliculary development is reactive oxsygen spesies (ROS) because of radio electromagnetic fields of Wi-Fi exposure. This study aimed to analyze the radiation effect of wireless fidelity (Wi- Fi) to oocyte number of oocyte stimulation in female mice (Mus musculus).

\section{MATERIALS AND METHODS}

Mice with radiation exposure of Wi-Fi as an exposure group was placed in particular room for Wi-Fi on 2.45 $\mathrm{GHz}$ frequency, located on Jalan Wahidin SHD 5, Gresik. On the other hand, control group was placed in safety area (far away from Wi-Fi), located in Hulaan Village, Menganti, Gresik. This place was safe from Wi-Fi radiation since it used detection tool to minimalize materials which able to trigger electromagnetic radiation, for example: TV antenna, radio, handphone, and microwave. Oocyte number were examined in laboratory of in vitro fertilization at Veterinary Medical Faculty, Universitas Airlangga. This was experimental study using control group with post test only design. The population of this study were two month old female mice (Mus musculus), weighing 20-25 grams.

This study used complete random sampling, and the sample were divided into two: control (R0) and exposure (R1). The samples were chosen by Federer formula, and the result obtained was $n=16$. The inclusion criteria of female mice (Mus musculus) were in health condition, active, aged two months and the weight was 20-25 grams. A number of 32 mice were obtained. On the other hand, the exclusion criterion was the mice that were dead during the experiment.

The exposure group of mice were placed closer to Wi-Fi source. There were two kinds of PC Laptop and two 3G phones placed in the right and left of the mice in 15 centimeter $(\mathrm{cm})$ distance. The mice received Wi-Fi radiation exposure for 15 hours/28 days. There was a control group as comparison. In control group, the mice were placed in special room which was far from Wi-Fi radiation exposure. This study used superovulation method to obtain more oocyte development and more ovulation of oocyte number. The mice were received Pregnant Mare Serum Gonadhotropin (PMSG) injection $5 \mathrm{IU}$ intraperitoneally at $01.00 \mathrm{PM}$. After 48 hours, they were received Human Chorionic Gonadhotropin (HCG) injection 5 IU intraperitoneally for oocyte maturation. Furthermore, they were mated to vasectomized male monomatingly to induce the ovulation. For 17 hours later, female mice were sacrificed using cervical dislocation method. Subsquently, the fertilization pouch of both oviducts were analyzed. 
In surgery section, both oviducts of mice were cut down, washed with Phospat Buffer Saline (PBS) liquid three times under medium drop M16 and observed for oocyte collection. The oocytes number were counted under inverted microscope to look for the fertilization pouch by sterile canule. Data were examined by Shapiro-wilk to observe the presence of normal distribution. The varian homogeneity were also examined by Levene's test method to observe the presence of homogeneity. Statistical tests used were independent sample T-test for normality distribution and data homogeneity and Mann whitney U test if there were no normality distribution and data homogeneity.

\section{RESULTS}

Table 1. Oocyte number in exposure (R1) and control (R0) group

\begin{tabular}{lcc}
\hline \multirow{2}{*}{\multicolumn{1}{c}{ Values }} & \multicolumn{2}{c}{ Groups } \\
\cline { 2 - 3 } & R0 & R1 \\
\hline Mean fertilization pouch & 2.000 & .0000 \\
Mean oocyte number & 21.7500 & .0000 \\
Std. Deviation & 8.7137 & .00000 \\
Normality test & \multicolumn{2}{c}{0.024} \\
Mann Whitney test & \multicolumn{2}{c}{ p value $=0.000$} \\
\hline
\end{tabular}

Tabel 1 shows that control group (R0) has mean value of 2.00. Whereas, exposure group (R1) has mean value of 0 (no fertilization pouch). It shows that Wi-Fi radiation exposure on $2.45 \mathrm{GHz}$ radio frequency fields is related to internet using laptop PCs and $3 \mathrm{G}$ phones for 15 hours/28 days. The observation result of fertilization pouch was 0 . It means that there was anovulation at exposure group.

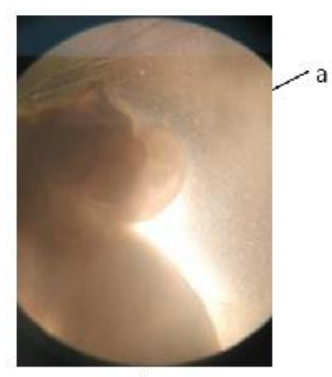

(1

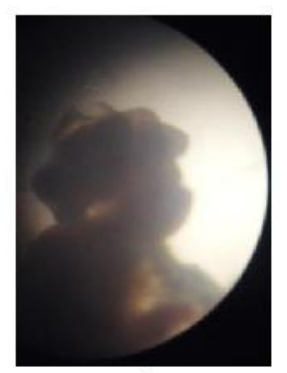

12
Fig. 1. The oviduct were observed under inverted microscope 400x, (1) the fertilization pouch (2) no fertilization pouch

The observation of fertilization pouch on female mice under inverted microscope is showed in Figure 2: (1) transparent fertilization pouch, (2) no fertilization pouch.
Female mice undergoing ovulation showed two fertilization pouches in the right dan left sides of the oviduct. When the fertilization pouches were opened, there were some oocytes. The data result of counted oocyte number and collection on female mice under inverted microscop are shown in Table 1. Statistical test using SPSS program showed that there was significant value $(\mathrm{p}$ value $=0.000$ ). It means that the oocyte number between control and exposure groups was significantly different.

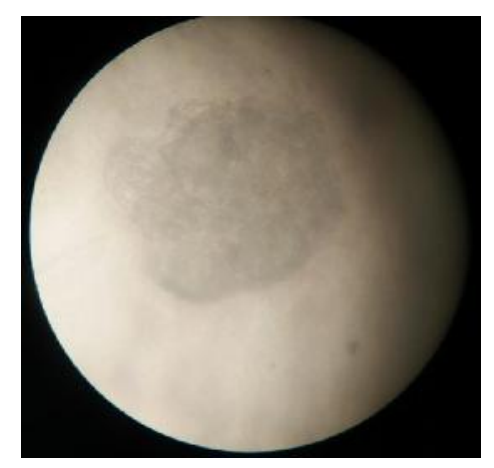

Fig. 2. Oocyte with cumulus oophorus observed under inverted microscop 200x magnification

Radiation exposure which produced by Wi-Fi radio electromagnetic fields for 15 hours $/ 28$ days in $15 \mathrm{~cm}$ distance could affect the oestrus cycle in mice, thus it could cause disrupted ovulation.

\section{DISCUSSION}

There has been considerable number of studies done in finding out the harmful effects of Wi-Fi radiation. The study by Jung et al (2007) proved that Wi-Fi radio electromagnetic fields could affect in oestrus cycle in mice because it may disrupt the physiological endocrine system which may disrupt reproductive organs. Alchalabi et al (2015) also did a study by giving $20 \mathrm{kHz}$ WiFi radio electromagnetic field exposure to two-week old mice with the distance of one meter from Wi-Fi source. The same study has been done by Vahid et al (2012) which showed that the exposure of Wi-Fi radiation in female mice for a month could decrease the secondary follicle number and de graaf which affected the steroidogenesis. Wi-Fi radiation exposure affected atresia follicle in ovarium and changed the stereoid hormonal concentration, and finally, it could affect the female mice fertility.

The electromagnetic field exposure by Extremely LowElectromagnetik Fields could affect female reproductive organ quality to undergo maturation because of apoptosis (Alchalabi et al 2015). The disruption of Gonado- 
thropin releasing hormone $(\mathrm{GnRH})$ secretion would disturb the secretion of follicle stimulating hor-mone (FSH) and Lutenaizing hormone (LH) by anterior hypophysis which caused folliculogenesis and oogenesis disruptions (the development process of follicle oocyte) (Sperrof \& Fritz 2011). Thus, it could decrease the quality and quantity of oocyte number. The oocyte observed were from female mice in A quality, in which its cumulus had compacting layer by two or three layers and homogeneous ooplasma. The oocyte which were collected from fertilization pouch underwent in vivo maturation. It occurred at folliculo-genesis and oogenesis which was affected by hormon regulation. The feedback mechanism system which was disrupted by Wi-Fi radiation exposure on the frequency of $2.45 \mathrm{GHz}$ for 15 hours/28 days could decrease the quality and quantity of oocyte.

Overall, the total of radiation which had been absorbed by human body depended on several factors, such as the frequency and electromagnetic on field length, the electromagnetic polarization, the distance between human body and electromagnetic radiation source, the condition of radiation exposure (e.g. other things around the radiation exposure), and the body characteristic (electricity of the body). The radiation will be more absorbed in body parts which have electricity, such as brain, muscle and other tissue which have high air concentration (Institutuo Edumed 2010).

\section{CONCLUSION}

Wireless fidelity (Wi-Fi) radiation has effect on oocyte number in mice oocyte stimulation. Therefore, the risk factors that may trigger electromagnetic radiation should be minimized to maintain reproductive health.

\section{REFERENCES}

Alchalabi, Ali. Aklilu, Erikhun (2015). Exposure to $1800 \mathrm{MHz}$ GSM-like radiofrequency electromagnetic field reduce follicular development and overall fertility of female rats. South Asian Journal 5, 127-136, ISSSN: 2230-9799

Institutuo Edumed (The edumed institute for education in medicine and health independent research group on the impacts of mobile technologies on health) (2010). Effect on human health. "with a review on the standarts and policies of radiofrequency radiation protection in Latin America"

Jung KA, Ahn HS, Lee YS, Gye MC (2007). Effect of a $20 \mathrm{kHz}$ sawtooth magnetic field exposure on the estrous cycle in mice. J Microbiol Biotechnol 17, 398402

Karki R (2013). The health risks of Wi-Fi. Dissertation, Turku University

Poulletier de Gannes F, Billaudel B, Haro E, et al (2013). Rat fertility and embryo fetal development: influence of exposure to the Wi-Fi signal. Reproductive Technology 36, 1-5

Sperrof L and Fritz M (2011). Clinical gynecologic endocrinology and infertility. 8th ed. Philadelphia: Lippincott Williams \& Wilkins, p 107

Vahid HJ, Dehghani K, Fatahi E, et al (2012). The effect of mobile phone waves on the reproduction physiology in adult female rats. Advance in Environmental Biology 6, 2735-274 